\title{
The Ottawa Field-Naturalists' Club Awards for 2016, presented February 2017
}

\author{
Eleanor Zurbrigg, Irwin Brodo, Julia Cipriani, Christine Hanrahan and Karen McLachlan Hamilton
}

On February $25^{\text {th }}, 2017$ members and friends of the Ottawa Field-Naturalists' Club gathered for the Club's Awards Night at St. Basil's Church in Ottawa to celebrate the presentation of awards for achievements in the previous year. Awards are given to members or nonmembers who have distinguished themselves by accomplishments in the field of natural history and conservation or by extraordinary activity within the Club. Five Club awards were presented for 2016, for: (1) further-

\section{Honorary Member: John McNeill}

This award is presented in recognition of outstanding contributions by a member or non-member to Canadian natural history or to the successful operation of the Club. Usually people awarded an honorary membership have made extensive contributions over many years.

It is a pleasure to award Honorary Membership in the Ottawa Field-Naturalists' Club to Canadian-Scottish botanist John McNeill. Long recognized as an international authority on vascular plant taxonomy and nomenclature, Dr. McNeill has also served important roles in academic and research institutions in both Ottawa and Toronto.

John McNeill was born in Scotland and earned his doctorate at the University of Edinburgh. After serving as a Lecturer at the University of Reading and University of Liverpool from 1957-1969, he came to Ottawa having accepted a position at the Plant Research Institute of Agriculture Canada (now called Agriculture and Agri-food Canada [AAFC]), and so began his long and productive period as a Canadian research botanist. Dr. $\mathrm{McNeill}$ contributed a great deal to the development of the plant systematics unit of AAFC and authored many papers on Canadian plants. One of his best known is "Grasses of Ontario" with William Dore. That monumental work may never have been completed without McNeill's collaboration. Other important titles concerning Canada were "The conservation of evolutionary centres in Canada", "The genus Atriplex in Canada", and several papers on the genus Polygonum. He also is an expert on the evolution of weeds and he contributed to the first complete inventory of Canadian weeds. During his years at the Central Experimental Farm in Ottawa, his door was always open to the professional and non-professional alike. He has always been both patient with enquiries and generous in his contributions to the work of others.

John McNeill is not only an accomplished researcher but also an extraordinary teacher, always ready to share his expert and vast botanical knowledge with anyone in need. In 1978 he took a short work transfer to the University of Toronto to assist in teaching plant systematics ing the knowledge of botany in Canada and internationally, (2) supporting communications activities of the Club, (3) long time service for the Club's online communications and Fletcher Wildlife Garden project, (4) habitat enhancement by engaging students in nest box construction, and (5) modifying habitat to help juvenile Snapping Turtles in Ottawa.

As well, a President's Prize was presented in recognition of unusual support of the Club's scientific journal.

when the program was without staffing. In 1981, he left AAFC to become Professor and Chair of the Department of Botany at the University of Ottawa. One of his Master's degree students at the U of O was Laurie Consaul, who became an accomplished botanist and was an avid birder well known to members of the Ottawa FieldNaturalists' Club.

Dr. McNeill returned to Scotland in 1987 to serve as Regius Keeper (Director) of the Royal Botanical Garden in Edinburgh. Only a few years later, he returned to Canada to teach at the University of Toronto and serve as Assistant Director of the Royal Ontario Museum, later becoming Director, and, in 1995, President of that institution. He remains Emeritus Director of the ROM.

Aside from his profound influence on hundreds of Canadian students and many Canadian botanists through his academic work, John McNeill served Canadian botany and the international botanical community as an expert on matters of biostatistics and botanical nomenclature. Any botanist anywhere in the world who has dealt with the names of plants using the International Code of Botanical Nomenclature, the global 'rule book' for the official naming of plant taxa, has benefitted from John McNeill's contributions in that field. As a Canadian botanist of international renown, he is rightly a major source of national pride.

Most recently, Dr. McNeill has been a major contributor to the on-going Flora of North America project, providing particularly critical input in two large and complex groups of plants, Caryophyllaceae (Pink Family) and Polygonaceae (Knotweed Family).

In 1999, he retired from the ROM and returned once again to Edinburgh where he has maintained a remarkably full program of pure and applied taxonomic research as Honorary Research Associate of the Royal Botanical Gardens, often doing editorial work with the journal, Taxon, dealing especially with nomenclatural issues, and, most significantly, he continues to play a large role in the revision and management of the International Code of Botanical Nomenclature and is the 
senior author of the current (Melbourne 2011) edition of the Code.

This combination of contributions both to science and to the research process itself on a regional, national, and global scale is remarkable if not unique. That in addition John McNeill has inspired and assisted the careers and discoveries of others makes his contribution to Canadian natural sciences all the more impressive.

\section{Member of the Year: Gordon Robertson}

The Member of the Year award recognizes a member judged to have contributed the most to the Club in the previous year.

We are recognizing Gordon Robertson as Member of the Year for his enthusiastic and willing support of a number of Club activities in 2016.

In 2016, Gordon took on the duties of Chair of the Education and Publicity Committee. He also undertook a number of activities on behalf of the committee. He has been extremely generous in response to requests to the OFNC from community groups for a nature talk or nature walk. These requests come in via the Club's website which invites people to email their request to edu cation@ofnc.ca, which is directed to Gordon.

Gordon created slideshows on various topics: migratory birds, waterbirds, butterflies, the Monarch Butterfly, and there are others. He delivered two workshops at the Fletcher Wildlife Garden (FWG) - one was for University of Ottawa education students and the other was for $\mathrm{U}$ of $\mathrm{O}$ teacher candidates. He gave nature talks to two grade seven classes at St. Francis Xavier High School. As well he co-staffed the OFNC display at several venues including Bug Day 2016 and at the Canadian Museum of Nature's NatureScene symposium.

Gordon led a number of nature walks, which when the walk was for kids, became a scavenger hunt. He led a nature walk through McCarthy Woods for the Riverside Park Community and Recreation Association, a

\section{George McGee Service Award: Sandra Garland}

This award is given in recognition of a member who has contributed significantly to the smooth running of the Club over several years.

Sandra Garland has been involved with the OFNC for many years and in many capacities. She has been active in the Publications, Fletcher Wildlife Garden, Computer Management committees, as well as in several ad hoc groups. Her contributions have been vast; however, the Club would like to highlight four of her outstanding accomplishments.

In 1997 Sandy responded to an ad in Trail \& Landscape looking for someone who was "fully conversant with HTML, and [could] surf the web in their sleep". From that point on, Sandy became known as the OFNC Webmaster. Her initial duties were to develop and coordinate committee sites, and to "perhaps provide inter-
OFNC Honorary Membership is appropriate for this long-time member of the Ottawa Field-Naturalists' Club (since 1970), acknowledging his impact on Canadian botany through his own publications and those of his Canadian students, as well as his international reputation as a leader on matters concerning botanical nomenclature.

(Prepared by Dan Brunton and Irwin Brodo, with assistance of Paul Catling and Jacques Cayouette)

nature walk co-led by Jakob Mueller for Friends of Petrie Island, a nature activity for a Mini Wheats camp (kids) at Watson's Mill, a nature walk for Girl Guides and Scouts in Winchester, and nature outings at the FWG for each of Brownies, Beavers, and homeschoolers.

Gordon also played an active role at the FWG, participating on the Management Committee, helping the Friday morning work crew, co-maintaining the bird feeders, maintaining the computer, and helping with many other tasks as needed. Over the past year, Gordon developed several posters for the FWG outdoor bulletin boards, and he is leading the creation of seasonal interpretive panels (storyboards) to be displayed at several locations in FWG.

Gordon also monitors the Club's Facebook posts fairly regularly and serves as liaison between the Facebook Group's administrators and the OFNC Board of Directors.

He attended the fall meeting of the Ontario Nature Eastern Region Network held at the Quinte Conservation Area and will be the OFNC's representative on this network.

It is for his enthusiastic contributions to many Club activities that we are recognizing Gordon Robertson with the Member of the Year Award for 2016.

\section{(Prepared by Eleanor Zurbrigg with input from} Lynn Ovenden)

linking via an OFNC website". It began as an information hub where she would update the site with material submitted by members of the various committees. That was 20 years ago, and things change over time. She continues to update the website regularly, but she also writes and edits articles posted on the OFNC blog and the Fletcher Wildlife Garden newsletter. She routinely fields queries submitted to the OFNC and will respond directly if she knows the answer or, if not, will forward the question to the right person. Thanks to Sandy, people receive answers as promptly as possible. She has also co-administered the Club's Facebook Group which has more than 1000 members. The hope in 1997 was to have a site that was dynamic, with continuous updates and new material posted regularly. Sandy has accomplished precisely that. 
Sandy is the force behind the Fletcher Wildlife Garden's annual Native Plant Sale. Her expertise and efforts to produce hundreds of native plants allow people to plant them in their gardens without destroying a patch in nature. Preparation for the sale begins in the fall when seeds are collected from Fletcher and some nearby sites. The seeds are then either stored indoors or potted and planted in the outdoor nursery. In January, the stored seeds are potted and propagated at the Interpretive Centre. From January to April, Sandy ensures that they have the proper light, moisture, and temperature requirements for producing healthy plants. If conditions are not right, the plants die leaving very little for the sale.

The devastation of the Old Woodlot after the Emerald Ash Borer moved through was immense. After 57 dead trees were removed, a number of non-native plants, such as burdock and Motherwort, took off. Then there is the continuous battle with Garlic Mustard and Dog-strangling Vine. The Old Woodlot desperately needed revitalizing, but it seemed like such a daunting task. Sandy accepted the challenge. She, on behalf of the Club, began by selecting nine native tree species from the Ferguson Forest Nursery, to be planted in the area. Then, on Tuesday afternoons, she coordinated the weekly volunteer duties that ranged from removing large non-native plants and invasives, to planting trees,

\section{Conservation Award - Member: Richard Waters}

The Conservation Award - Member is given in recognition of an outstanding contribution by a member in the cause of natural history conservation in the Ottawa Valley, with particular emphasis on activities within the Ottawa District.

For 2016 we are recognizing the impact Richard Waters has had on the Bell High School students in his grade nine Exploring Technology class. As a teacher, his challenge was to generate students' interest to make something that they would be proud enough of to take home with them and to get their credit for grade nine Exploring Technology as required by the Ontario curriculum. The outcome of his work with over 1000 students since 2008 is a great deal of pride in their creations and an interest in birding - feeding, housing, and protecting the birds' habitats.

The seeds of Richard's work with the students were planted by Chris Traynor of the Ottawa Field-Naturalists' Club and Chris Bruce of the Macnamara Field Naturalists' Club. Chris Traynor mentioned to Richard that there was a need to replace some owl boxes that were falling apart after 20 years of service. Chris Bruce suggested that Richard's students make Eastern Bluebird boxes for the Bell Arena Woods area behind the high school.

Richard guides his students through a process to identify a local species and to investigate their habitat. The students generate a design specification for the outcome they are looking for and identify performance shrubs, and wildflowers, to hunting down saplings planted the previous year that were engulfed by weeds.

A new strategy for tackling large or difficult projects was recently adopted at the FWG. The strategy is to create "nodes", a place or feature where volunteers work to create, preserve, or protect the flora and fauna within. A node is small enough that a volunteer can work on it independently and will be able to see results within a short period of time. Examples include: brush piles, Dog-strangling Vine "crop circles", or the insect motel. It was Sandy who volunteered to become the coordinator of the node-nanny group where she solicited volunteers and would help them get started on their various nodes. She became the Tuesday afternoon go-to person who would welcome the node nannies, open the sheds, and chat with them about their goal for the day and a strategy of achieving that goal.

If all of the above is not enough, Sandy continues to support public outreach at the FWG and, more recently, has taken on the duties of Copy Editor for The Canadian Field-Naturalist.

Awarding the George McGee Service Award to Sandy Garland is a fitting response to her long and dedicated service to the Ottawa Field-Naturalists' Club. Congratulations Sandy!

(Prepared by Karen McLachlan Hamilton)

criteria. He teaches students to draw designs of the nest box in two dimensions and in three dimensions, to produce a plan, to use the tools, materials, and machinery in the shop, and guides them through to a finished product.

Richard oversees the process, drawing on the help and advice of his local birding network at Innis Point Bird Observatory and fellow OFNC birders for input on types of boxes and location to target conservation needs. Finding suitable habitat for species in need is important. Locations have to be accessible, yet out of sight to avoid vandalism or disturbance. Richard and his team monitor a constantly growing number of boxes throughout the year. Richard provides feedback and photos to the students. Some students have continued an interest. Richard has them count birds twice a week for the FeederWatch project!

Richard and his students have been successful in providing boxes for a growing list of species, which includes Purple Martin, with a grant from World Wildlife Fund and Loblaw Ecogrant (\$850), Eastern Bluebird, Eastern Screech Owl, White-breasted Nuthatch, Tree Swallow, House Wren, Downy Woodpecker, Redbellied Woodpecker, bee boxes, and flying squirrels' nesting boxes. They have installed a web cam for Bell High School's FeederWatch project with live footage streamed into the Science and Technology classrooms via the school's network. 
Upcoming projects for which Richard and his students have created designs and bid proposals include tree planting, outdoor classrooms, and butterfly gardens.

We are pleased to recognize the work of Richard Waters with this Conservation Award for a member.
Richard's students' creations may be seen at http://www .pbase.com/rwaters/purple_martin_house_project\&pa $\mathrm{ge}=$ all.

(Prepared by Julia Cipriani)

\section{Conservation Award - Non-Member: City of Ottawa}

This award is given in recognition of an outstanding contribution by a non-member in the cause of natural history conservation in the Ottawa Valley, with particular emphasis on activities within the Ottawa District.

This year the award goes to the City of Ottawa's planning and environmental engineering groups for their efforts to help hatchling Snapping Turtles make it safely to Mud Lake at the Britannia Conservation Area. Snapping Turtles are officially listed as a species at risk federally and provincially.

It has been known for quite some time that the hatchling Snapping Turtles were being killed on the road to the water filtration plant at the Britannia Conservation Area. Female Snapping Turtles emerge from the lake every June to lay their eggs. Although they may head in any direction, many travel north from the lake and lay their eggs in the gardens and open areas around the filtration plant. Every fall the eggs hatch and the tiny hatchlings head for the lake - or sometimes away from it.

While those hatchlings from nests close to the lake need travel only a few metres, others must cross the road to reach Mud Lake. Being hit by a car is always a danger, but much more problematical was the road's curb. Although the turtles could tumble down the curb and cross the road, they could not get up and over the curb on the other side by the lake and were trapped on the road.

\section{President's Prize: Carolyn Callaghan}

This award is given at the President's discretion in recognition of a member for unusual support of the Club and its aims.

I would like to acknowledge Carolyn Callaghan for exceptional accomplishments during her tenure as Editor-in-Chief of The Canadian Field-Naturalist (the CFN).

Carolyn served as Editor from 2011 to 2016, leading production of volumes 125 to 130(1), and as outgoing Editor-in-Chief for volume 130(2-3) during the smooth transition to a new Editor. For some six years, beginning in 2010, Carolyn successfully led a large team including two Assistant Editors, a Book Review Editor, a Tributes Editor, multiple Associate Editors, Copyeditors, a typesetter, and two webmasters, while working closely with the OFNC Publications Committee and the OFNC Board of Directors, and engaging with hundreds of communicating authors of manuscripts and peer reviewers.
The curb was only about $14 \mathrm{~cm}$ tall, but from the viewpoint of a 3 -cm-long hatchling, it was an insurmountable cliff. Hatchlings could follow the curb and, maybe, find a gap, but this might be $25 \mathrm{~m}$ away. Many died from dehydration under the hot sun on the road - or were eaten.

The OFNC Conservation Committee began working with the city on this issue in early 2015 , and a solution was put in place in autumn 2015 . The city removed the vertical curbs along the south side of the road and replaced them with sloped curbs. The gradual slope means that hatchling Snapping Turtles can now cross the road and continue their trek to Mud Lake. During autumn 2016, hatchling turtles were observed using the new curbs to safely reach Mud Lake.

We applaud the City of Ottawa, working with the Britannia Water Purification Plant, for their quick response to this issue, which goes a long way to helping more of the at risk Snapping Turtles survive.

For their positive and speedy response to concerns regarding safety of Snapping Turtles at Britannia Conservation Area, the OFNC is honored to present the City of Ottawa's planning and environmental engineering groups with its Conservation Award for a non-member.

(Prepared by Christine Hanrahan based on material from David Seburn found at https://ofnc.wordpress.com /2015/11/13/victory-for-the-snapping-turtles)

Carolyn returned the CFN to a regular schedule of publication, and under her editorship the journal made the transition to electronic publishing in addition to the standard hard-copy version of the journal.

Carolyn demonstrated particularly strong leadership in encouraging youth in science. She accepted for publication two papers (in volume 127(3)) reporting original research conducted by two high school students, encouraging these young scientists in their work and continuing a long OFNC tradition of mentoring young naturalists.

The job of Editor-in-Chief for a science journal is a demanding one, and Carolyn succeeded in this role for The Canadian Field-Naturalist. I am pleased to present her with the President's Prize.

Since June 2016, Dr. Carolyn Callaghan is a Senior Conservation Biologist with the Canadian Wildlife Federation.

(Prepared by Diane Lepage, President, based on material from Jeff Saarela) 